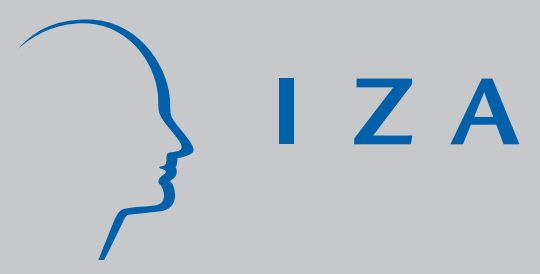

IZA DP No. 2821

Are Workers in the Cultural Industries Paid Differently?

Cecile Wetzels

May 2007 


\title{
Are Workers in the Cultural Industries Paid Differently?
}

\author{
Cecile Wetzels \\ FEE, University of Amsterdam \\ and IZA
}

Discussion Paper No. 2821

May 2007

\author{
IZA \\ P.O. Box 7240 \\ 53072 Bonn \\ Germany \\ Phone: +49-228-3894-0 \\ Fax: +49-228-3894-180 \\ E-mail: iza@iza.org
}

Any opinions expressed here are those of the author(s) and not those of the institute. Research disseminated by IZA may include views on policy, but the institute itself takes no institutional policy positions.

The Institute for the Study of Labor (IZA) in Bonn is a local and virtual international research center and a place of communication between science, politics and business. IZA is an independent nonprofit company supported by Deutsche Post World Net. The center is associated with the University of Bonn and offers a stimulating research environment through its research networks, research support, and visitors and doctoral programs. IZA engages in (i) original and internationally competitive research in all fields of labor economics, (ii) development of policy concepts, and (iii) dissemination of research results and concepts to the interested public.

IZA Discussion Papers often represent preliminary work and are circulated to encourage discussion. Citation of such a paper should account for its provisional character. A revised version may be available directly from the author. 


\begin{abstract}
Are Workers in the Cultural Industries Paid Differently?
Wage differentials between three sub-industries of the cultural industries and their respective main industry: The case of the Netherlands

This paper aims to explore wage differentials between employees in three sub-industries of the cultural industries compared with the main (1-digit level) industry to which they belong. We use data from the Wage Indicator Questionnaire 2001/2002, which includes information on 12,757 employees in the Netherlands. We find that workers in these particular subindustries of the cultural industries are paid differently compared with their respective main industries. Workers in entertainment and publishing and printing are less endowed with standard labour market characteristics. However, whereas workers in entertainment face negative price or evaluation-related effects, the opposite holds for workers in publishing and printing. Workers in IT are more endowed with standard labour market characteristics, but they receive lower rewards for their labour market characteristics.
\end{abstract}

JEL Classification: J24, J31, L82, O12

Keywords: decomposition, entertainment, IT-services, Netherlands, printing and publishing, wage differentials

Corresponding author:

Cecile Wetzels

Faculty of Economics and Econometrics

University of Amsterdam

Roetersstraat 11

1018 WB Amsterdam

The Netherlands

E-mail: cwetzels@fee.uva.nl 


\section{Introduction}

Most artists are poor and only few of them are among the best-paid professionals (Abbing, 2002). Throsby (1994, p.18) reveals a considerably lower level of mean and median earnings among artists than among other workers of similar educational and professional standing. Artistic and comparable creative jobs are the core occupations in some sub-industries of the cultural industry as a whole. Earnings in core occupations within an industry are correlated with earning levels in the industry. Osburn (2000), for example, points to the fact that the occupations most strongly affected by factors resulting in wage differentials across industries are those that have duties and tasks which are the most closely involved in the primary activities of the firm. What do the low earnings of artists, therefore, teach us about the earnings in the cultural industries? In this study, we will examine wage levels in sub-industries of the cultural industries (e.g. IT) rather than in specific cultural occupations (e.g. computer games designers). Thus we will not analyse the incomes of the self-employed or freelancers, typical conditions for artists, because we would then have to analyze prices and their determinants, such as the characteristics of the artists' products (see e.g., Rengers and Velthuis, 2002). Instead, we turn to the commonly used analyses of wages of individuals in wage employment. Osburn (2000) also based her findings on workers in wage employment.

In seeking answers to the question of whether workers in the cultural industries are paid better or worse than other workers, this article investigates wage levels in three sub-industries of the cultural industry (which is not yet defined as an industry in the official coding of the Dutch Statistical Office) and compares them with the wages paid in the main 1-digit industry to which each sub-industry belongs. In Section 2 the theoretical explanations for wage differentials across industries and for wages in the cultural industries in particular are examined. Furthermore, we define what is meant by the term cultural industries, identify these industries and make our hypotheses. Section 3 explains the models used to estimate earnings equations and a decomposition technique for the identification of wage gaps. Section 4 describes the data used and the cultural industries in our data set. Section 5 presents the results of wage regressions by the sub-industries of cultural industries and their respective main industry. Section 6 shows the wage differences between the three sub-industries of cultural industries, compared with their respective main industries, and discusses what part of these wage differences is explained by differences in workers' characteristics and what part remains unexplained. Finally Section 7 draws a number of conclusions. 


\section{Explaining Wage Differentials across Industries}

In exploring the question of why workers in the cultural industries may be paid differently from other workers in paid employment, several theories and empirical findings are at our disposal. One strand of the literature is based on investigations of inter-industry wage differentials with no particular reference to the cultural industry. A second strand of the literature is based on investigations of wages in the cultural industry, mostly without detailed comparisons with wages in other industries. Furthermore, we will discuss various definitions of the cultural industries.

\subsection{A Short Review of Earlier Studies}

Considerable evidence exists for a wide dispersion in wages across industries. Inter-industry wages' differentials appear to be highly persistent over time, and the tendency to converge is extremely weak (Krueger and Summers, 1988). Moreover, high-paying industries are the same across various countries. The reasons for why industries pay higher wages break down into: (1) the shirking model, which indicates that high wages will be paid because monitoring is difficult or costly, particularly in large establishments; (2) the turnover model, which indicates that high wages are used to reduce turnover, particularly when training costs are high; (3) the selection model, which indicates that high wages are used to attract a better quality workforce; and (4) the sociological model, which indicates that high wages are used to improve worker morale (Fields and Wolff, 1995). Other explanatory models that predict that firms find it profitable to pay above market wages refer to either standard competitive labour market theories, pointing to capital intensity, concentration, geographical characteristics, and rent sharing, whereby the remaining variation is generally thought to be caused by compensating wage differentials; or they refer to the non-competitive approach, whereby it is assumed that efficiency wages explain the interindustry wage variation (Blackburn, 1995) taking into account human capital variables, based on a large strand of the literature and empirical findings. The literature on inter-industry wage differentials has also reflected on the question whether all measured wage differentials are true, or whether part of these differentials simply reflects unmeasured differences in workers' productive abilities (Gibbons and Katz, 1992). As Gibbons and Katz (1992, p. 530) conclude: "We know of no model that fits all facts. ... Perhaps no single theory can provide a complete explanation of inter-industry wage differences because different theories are of the greatest importance in different sectors of the labor market.” Bartel and Sicherman (1999), who use an inter-industry analysis to explain the wage premium and the education premium associated with technological change, find that the wage premium is primarily caused by the sorting of more able workers into industries associated with technological change, whereas the education premium is the result of the greater demand for the innate ability or other observed characteristics of more 
educated workers. However, the extensive literature on inter-industry wage differentials does not specifically address or analyse the inter-industry wage differentials in the cultural industries. Our aim is to fill this gap. We believe that the cultural industries comprise different markets of gainful employment, and therefore we will analyse three sub-industries. Before we make our hypotheses on inter-industry wage differences regarding these cultural sub-industries, we will first review studies on earnings in the cultural industries and explain what we mean by the cultural industries.

The second strand of the literature relevant for our investigation covers the cultural industries only, focusing on the performing, visual, and literary arts. Throsby (1994) reviews the major findings regarding artists' earnings. Using US census data, a considerably lower level of mean and median earnings is revealed for the occupational groups in which artists are classified, compared with other workers of similar educational and professional standing (Thorsby, 1994, p. 18). Artists suffer a significant earnings penalty, which is partly because they have lower hourly earnings and partly because artists spend less time on their work than other workers do in their occupations. Moreover, age-earnings profiles are steeper for artists than for other workers. Education, which is a major human capital variable in explaining wages, appears not to be as influential for artists as it is for other occupations: the schooling variable turns up with lower and less significant coefficients for artists than for other occupations. Finally, the exploration of artists' incomes shows that they are more variable over time and for different types of artist. In order to earn a decent income, moonlighting is common among artists. Blaug's (2001) review of developments in the economics of the performing, visual, and literary arts over the last 30 years, shows that only an older study by Filer (1986), which used a less rich and less individual data set compared with studies in the 1990s, found that the human capital theory (Becker 1962, Mincer 1974) works for artists as well as for other workers. All other studies do not find an effect of education of the kind expected from human capital theory. Another strand of the literature on the cultural professions follows the seminal work by Rosen (1981) on the economics of superstars. Rosen drew attention to the size of the market and the proportion of it that is controlled by a single person. Indeed, in certain kinds of economic activity there is a concentration of output among a few individuals, which is also shown in the distribution of income, and in very large rewards at the top. In this paper we focus on workers in wage employment in sub-industries of the cultural industry. However, we do not aim to analyse the distribution of earnings and the impact of superstars in certain specific markets of the cultural industries.

\subsection{Identifying the Cultural Industries}

It is generally agreed that the term 'cultural industries' applies to those industries that combine the creation, production and commercialization of contents, which are intangible and cultural in 
nature. These contents are typically protected by copyright, and they take the form of goods or services. Depending on the context, cultural industries may also be referred to as "creative industries", "sunrise” or "future-oriented industries" in economic jargon, or "content industries" in technological jargon. The notion of the cultural industries generally includes printing, publishing, and multimedia, audio-visual, phonographic and cinematographic productions, as well as crafts and design. For some countries, this concept also embraces architecture, visual and performing arts, sports, manufacturing of musical instruments, advertising, and cultural tourism. ${ }^{2}$ However, some dispute remains as to the definition of the Cultural Industries (Pagniet, 2002). A major reason for this dispute lies in the fact that the cultural industries are dynamic industry, with both horizontal integration as new players enter from telecommunications and computer industries, and vertical integration, with media firms getting involved in all areas of media content production and distribution (Ducatel et al., 2000). It is expected that increasingly large international conglomerates will unite businesses from almost every sub-industry of the cultural industries, and that the arrival of the Internet and digitalized information will have a far-reaching influence on the future of the cultural industries (Rutten, 1999).

These definitions of the cultural industries are not easily identified in officially accepted industry coding systems, such as those that are employed by national or international statistical offices. To identify the cultural industries, we have chosen a broad range of sub-industries using a coding method based on the Standard Industry Coding (SBI-1993) of Statistics Netherlands (CBS, 1993). At the 3-digit level of classification we defined three sub-industries within the cultural industries: namely, (1) printing and publishing: (2) IT-services: we defined these in order to capture IT-firms that fuse into cultural markets, and cultural firms that employ IT extensively and therefore may be now coded as IT-services firms, and (3) the entertainment industry, including advertising. To facilitate the understanding of a worldwide readership, we also used the corresponding codes of the General Industrial Classification of Economic Activities within the European Communities, abbreviated to NACE-Rev.1. Table 1 presents the NACE-codes and their equivalent SBI-codes. ${ }^{3}$

At the 3-digit level of classification, the printing and publishing industry consists of two branches: the printing industry and the publishing industry (NACE codes 473 and 474). The ITservices and the Internet firms cannot be identified as separate branches of industry in the NACE-Rev-classification, most probably because this classification lags behind the recent and fast developments in the IT industry. The corresponding NACE-code 839.2 includes all kinds of IT-related services. At the 3-digit level of classification, the entertainment industry breaks down into five branches of the industry, which include: cinemas; radio and television services; entertainment; liberal, artistic and literary professions and libraries; we also included advertising, 
because this branch increasingly includes artistic professionals. The corresponding NACE-codes are 973 to 977 , and 838.

With a view to testing the assumption of wage differentials, each of the three sub-industries of the cultural industries under study is compared with the remaining branches at its one-digit classification (Table 2). Thus, the printing and publishing industry is compared with other branches in the manufacturing industry, including agriculture, construction and transport. The ITservices and Internet firms are compared with the trades and commercial services. The entertainment industry is compared with the non-commercial services and the public sector. In this analysis we will keep constant some major inter-industry differences irrelevant to our research objective, such as public versus private industries.

Table 1 Identifying three sub-industries of the cultural industries

\begin{tabular}{|c|c|}
\hline NACE-Rev-1 CODING\# & SBI-1993 CODING\#\# \\
\hline \multicolumn{2}{|l|}{ PRINTING AND PUBLISHING } \\
\hline 473, 474 printing and publishing & 220 \\
\hline $\begin{array}{l}473 \text { printing industry, gravure printing, letterpress, bookbinding, } \\
\text { including sewing and gilding, industries allied to the printing industry }\end{array}$ & 222 \\
\hline $\begin{array}{l}474 \text { publishing of books, pictures, music, newspapers and periodicals, } \\
\text { other publishing }\end{array}$ & 221 \\
\hline \multicolumn{2}{|l|}{ IT-SERVICES AND INTERNET FIRMS } \\
\hline $\begin{array}{l}839.2 \text { Computer services and services provided by means of office } \\
\text { machines (duplicating, document copying, etc.) to third parties on a fee or } \\
\text { contract basis }\end{array}$ & $\begin{array}{l}720+ \\
721\end{array}$ \\
\hline \multicolumn{2}{|l|}{ ENTERTAINMENT INDUSTRY } \\
\hline 973 Cinemas & 921 \\
\hline $974 \quad$ Radio and television services & 922 \\
\hline 975 Entertainment (except cinemas and sport) & 925 \\
\hline 976 Liberal, artistic and literary professions & $923+924$ \\
\hline $\begin{array}{l}977 \text { Libraries, public archives, museums, botanical and zoological } \\
\text { gardens }\end{array}$ & 925 \\
\hline 838 Advertising & 744 \\
\hline
\end{tabular}

\# Codes and names in the NACE Rev-1 coding from Eurostat. \#\# SBI-1993 coding from Statistics Netherlands. 
Table 2 The three sub-industries of the cultural industries, the main industries to which they belong, and the abbreviations used in this study.

\begin{tabular}{|l|l|l|l|}
\hline Sub-industry (3-digit) & $\begin{array}{l}\text { Abbreviated } \\
\text { to }\end{array}$ & Main industry (1-digit) & Abbreviated to \\
\hline Printing and Publishing & P\&P & $\begin{array}{l}\text { Agriculture, manufacturing, construction and } \\
\text { transport }\end{array}$ & Manufacturing \\
\hline $\begin{array}{l}\text { IT-services and Internet } \\
\text { firms }\end{array}$ & IT-services & Trades and commercial services & $\begin{array}{l}\text { Commercial } \\
\text { services }\end{array}$ \\
\hline Entertainment industry & Entertainment & $\begin{array}{l}\text { Non-commercial services and the public } \\
\text { sector }\end{array}$ & $\begin{array}{l}\text { Non-commercial } \\
\text { services }\end{array}$ \\
\hline
\end{tabular}

\subsection{Expectations}

Table 3 summarizes explanations for wage differentials between industries, and expectations for wages in the cultural industries compared with their respective main industries. We expect the wages of workers in publishing and printing not to be different from the wages of other workers in the main industry, since the shirking model, the turnover model, the selection model, and technological change and human capital investments do not lead to the expectation of high wage differentials. In addition, we expect the workers in IT-services to earn higher wages than other workers in trades and commercial services. IT, as a relatively new field, requires not only investments in schooling and training (turnover model) but also creativity (selection model). Moreover, most industries, including the entertainment industry, are in need of IT workers, because the arrival of the Internet and digitalized information has created one distribution medium for different cultural product categories and for different industries (Rutten, 1999). Furthermore, a new category of workers, digital information managers, has grown. They receive products from content producers, and earn their income by exploiting access to consumers. This latter category of workers may be closely related to either computer software engineers or traditional content providers, such as, for example, providers of music, film, and novels that innovate and employ the new IT-technologies. In the Netherlands, IT-firms have emerged near technical universities in the Provinces of North-Brabant (Technical University Eindhoven) and South Holland (Technical University Delft).

From Section 2.1 it follows that workers in the performing, visual and literary arts probably earn lower wages than other workers in non-commercial services and the public sector. However, some firms in entertainment have become large (i.e. those in television and theatre production) which is expected to have a positive effect on wages if the monitoring costs theory (shirking model) applies. In addition, working in the Province of North-Holland (which has TV studios in 
Hilversum and a high concentration of film, advertisement and media-related industries in Amsterdam), and South-Holland (which has a high concentration of media and entertainment companies, architecture and design businesses in Rotterdam) may lead to higher wages in the cultural industries compared with other non-commercial services. The density of (networks of) firms in the urban context (Kloosterman, 2004) may be an indicator for the selection model. On the other hand, most workers in large organizations in non-commercial services and the public sector will probably also earn higher wages, because these include a high proportion of rather well-paid civil servants. These workers are mostly located in The Hague, where the Dutch government is located, which is in the Province of South-Holland.

Table 3 Expectations of wage differentials in the cultural industries

\begin{tabular}{|c|c|}
\hline $\begin{array}{l}\text { Explanations for } \\
\text { industries paying higher } \\
\text { wages }\end{array}$ & $\begin{array}{l}\text { Expectations regarding workers' wages in cultural industries (3-digit) vs. main } \\
\text { industries (1-digit) }\end{array}$ \\
\hline Shirking model & $\begin{array}{l}\text { Conglomerates and large companies in television and theatre production, } \\
\text { the music industry, and IT firms are expected to have higher monitoring costs and } \\
\text { therefore may make industry pay higher wages. However, this applies similarly to } \\
\text { other industries. } \\
\text { Both the production and consumption of cultural goods may be more } \\
\text { demanding and less predictable than that of non-cultural goods, and therefore it } \\
\text { may make monitoring costs higher. This could lead to higher wages for employees } \\
\text { in those cultural industries with the most unpredictable markets, e.g. as artists, } \\
\text { designers and other kinds of workers in the entertainment industry. }\end{array}$ \\
\hline Turnover model & $\begin{array}{l}\text { Training costs are especially high in technologically-advanced production } \\
\text { and distribution. According to six indices for industry rates of technological change } \\
\text { (Bartel and Sicherman*, 1999), IT rates the highest in technological innovation (1), }_{\text {followed by entertainment (2), and P\&P (3). We may expect higher rates of }} \text { technological change and higher wages in IT-firms, compared with commercial } \\
\text { services. } \\
\text { Creative qualifications or talents may bloom as a result of change in work } \\
\text { settings (internal/external). It is unclear how this may affect wages. }\end{array}$ \\
\hline Selection model & $\begin{array}{l}\text { Employees with specialized qualifications may earn higher wages than } \\
\text { those in the 1-digit industry concerned. This may be more prevalent in ITservices } \\
\text { and entertainment than in their respective main industry. }\end{array}$ \\
\hline
\end{tabular}




\begin{tabular}{|l|l|}
\hline Innovation & $\begin{array}{c}\text { Kloosterman (2004:244) points out that the creation of cultural products } \\
\text { which are 'unique' in terms of quality, complexity or image constitutes, first and } \\
\text { foremost, conceptual innovation. If conceptual innovation led to similar effects as } \\
\text { those of technological innovation, regarding the education premium and the wage } \\
\text { premium, we would expect higher wages in the entertainment industry, and less in } \\
\text { P\&P, compared with their respective main industry. However, the relatively minor } \\
\text { effects of human capital on artists' earnings may also affect the wages of other } \\
\text { workers in the cultural industries negatively. On the other hand, new } \\
\text { internationally successful firms, e.g. Dutch Design, may have the market power to } \\
\text { demand higher wages for talent in combination with high skills. }\end{array}$ \\
\hline
\end{tabular}

* The indices used in (B\&S) (1999) refer to the US and to earlier periods. However, we wish to derive a rating indicating (1) the most technologically advanced to (3) the least technologically advanced. In B\&S (1999) printing and publishing is among the lowest according to the rating of their 6 indicators, and electronics scores among the highest.

The inter-industry wage analyses are typically controlled for the standard human capital variables, that is, education, age or years of service, gender, and race. In addition, studies of the gender wage gap reveal that some variables have a different effect on men's and women's wages, particularly when it comes to the association between motherhood and wages. For the Netherlands, Wetzels and Tijdens (2001) found that a career break for the purpose of child rearing had a large impact on Dutch women's wages. Therefore, apart from the human capital variables we will take an individual's household characteristics and career break into account in our analyses of the wages in the cultural industries. Furthermore, wages may differ by gender even if similar levels of education and years of employment experience are attained. We include interaction variables to control for these possible effects. In addition we control for job characteristics such as employment contract and working part-time. Following the reasoning of the shirking model, we expect wages to be determined by firm size, and therefore we include this variable. We also control for region.

\section{Empirical Model}

\subsection{Methodology}

This paper aims to explore wage levels in the cultural industries in comparison with wage levels in the aggregated industries of which each of them is a part. We will estimate wage differences in each sub-industry compared with the 1-digit level industry to which they belong. The analyses 
follow a two-step methodology. First, we estimate whether wage differences exist between employees in the three cultural sub-industries compared with their respective 1-digit industries, taking into account the explanatory factors derived from Section 2. The standard procedure to identify wage differentials is to estimate Mincerian wage functions by OLS. Second, different wage levels are analysed following the literature on decomposing wage differentials. This literature explains a certain part of the differences in wages by differences in workers' observable labour market qualifications. Furthermore, an unexplainable part of the differences is considered to comprise price or evaluation-related effects. We measure the wage gap by simply including dummies in these wage functions, or, alternatively by decomposing wage differentials by the method developed by Oaxaca (1973).

However, numerous recent econometric studies indicate that non-random sampling can have deleterious effects on the properties of OLS estimations. In the literature this is referred to as a selectivity problem. The productivity and behaviour of those who are included in this nonrandomly selected sample may be different from that of those who are not included in the sample. This may cause a bias with regard to the estimated coefficients of the earnings functions (Heckman, 1979). Unfortunately our data set excludes unemployed persons, so we are unable to control for them.

\subsection{Estimation of Wage Equations}

We apply a conventional earnings function: $\ln W_{i j}=X_{i j} \beta_{j}+\varepsilon_{i j}$,

where $\ln W_{i j}$ is the natural logarithm of hourly earnings; $X_{i j}$ are vectors of exogenous regressors determining productivity; and $\beta_{j}$ are coefficient vectors of the wage equation. Individuals are indexed by $i=1,2, \ldots, n$, and industry by $j=1,2, \ldots, 6 ; \mathrm{j}=1=\mathrm{P} \& \mathrm{P} ; \mathrm{j}=2=$ Manufacturing, excl. P\&P; $j=3=$ IT Services; $j=4=$ Commercial Services, excl. IT Services; $j=5=$ Entertainment Industry; $\mathrm{j}=6=$ Commercial services. The error term $\varepsilon_{\mathrm{ij}}$ is independently and identically distributed within each main industry $\mathrm{j}\left[\varepsilon_{i j} \approx N\left(0, \sigma_{j}\right)\right]$. First, wage equations for employees in the selected main industries and sub-industries are estimated. Secondly, wage differentials between workers in the selected sub-industries and main industries will be decomposed into productivity differentials and price or evaluation-related effects (Blinder, 1973; Oaxaca, 1973).

\subsection{Calculation of Wage Differentials via Decomposition}

In essence the Blinder decomposition of wage differentials takes the average endowment differences between the two groups (the wages of the workers in the sub-industry and the wages 
of workers in their respective main industry) and weights them by the estimated coefficients of the high-wage workers, while the differences in the estimated coefficients are weighted by the average characteristics of the low-wage workers. The decomposition is explained as follows.

Let $\mathrm{y}_{1}$ and $\mathrm{y}_{2}$ be the means of the dependent variable $\mathrm{Y}\left(\mathrm{Y}=\ln \mathrm{W}_{i j}\right), \mathrm{x}_{1}$ and $\mathrm{x}_{2}$ the row vectors of the means of the explanatory variables $X_{1}, \ldots, X_{k}$, and $b_{1}$ and $b_{2}$ the column vectors of the coefficient for group 1 (high) and group 2 (low). Group 1 (high) are wages in the sub-industries. Group 2 (low) are wages in the respective main industries. For each pair of sub-industry and main industry, the raw differential $\mathrm{y}_{1}-\mathrm{y}_{2}$ may then be expressed as:

$$
\mathrm{R}=\mathrm{y}_{1}-\mathrm{y}_{2}=\left(\mathrm{x}_{1}-\mathrm{x}_{2}\right) \mathrm{b}_{2}+\mathrm{x}_{2}\left(\mathrm{~b}_{1}-\mathrm{b}_{2}\right)+\left(\mathrm{x}_{1}-\mathrm{x}_{2}\right)\left(\mathrm{b}_{1}-\mathrm{b}_{2}\right)=\mathrm{E}+\mathrm{C}+\mathrm{CE} .
$$

(Daymont and Andrisani 1984), i.e. $\mathrm{R}$ is decomposed into: a part due to differences in endowments (E) or characteristics; a part due to differences in coefficients (including the intercept) (C) and attributed to price or evaluation related-effects; and a part due to interaction between coefficients and endowments (CE). Depending on the model which is assumed to be non-discriminating, these terms may be used to determine the unexplained (U; discrimination) and the explained (V) part of the differential (the question is how to allocate the interaction term CE). Oaxaca (1973) proposed to assume either the low group model or the high group model as non-discriminating, which leads to $\mathrm{U}=\mathrm{C}+\mathrm{CE}$ and $\mathrm{V}=\mathrm{E}$ or $\mathrm{U}=\mathrm{C}$ and $\mathrm{V}=\mathrm{E}+\mathrm{CE}$, respectively. More generally the decomposition may be written as:

$$
\mathrm{y}_{1}-\mathrm{y}_{2}=\left(\mathrm{x}_{1}-\mathrm{x}_{2}\right)\left[\mathrm{D} * \mathrm{~b}_{1}+(\mathrm{I}-\mathrm{D}) * \mathrm{~b}_{2}\right]+\left[\mathrm{x}_{1} *(\mathrm{I}-\mathrm{D})+\mathrm{x}_{2} * \mathrm{D}\right]\left(\mathrm{b}_{1}-\mathrm{b}_{2}\right) .
$$

where $\mathrm{I}$ is a identity matrix and $\mathrm{D}$ is a diagonal matrix of weights. In our analysis, D is a nullmatrix or equals I ( $\mathrm{D}=\mathrm{I}$ is also what Blinder, 1973, suggested).

The Oaxaca technique was initially developed for analysing price or evaluation-related effects using cross-section data. Since then, it has also been applied to panel data. However, it does not take into account the effects of changes in the overall wage distribution on the wage gap. Altonji and Blank (1999) extensively discuss the (dis) advantages of different approaches that measure price or evaluation-related effects. Since we use cross-sectional data, we will not further discuss the dynamic aspects of wage differentials here.

\section{Data, Measurement, and Descriptive Statistics}

\subsection{The Data from the Wage Indicator Questionnaire 2001/02}

For the empirical research, we used data from the Wage Indicator Questionnaire (WIQ) 2001/2002 (WIQ-2001/02), which is part of the Wage Indicator Website (www. loonwijzer.nl) 
(see Tijdens et al. 2002; Tijdens, 2004). The website comprises a cooperation of the largest Dutch trade union confederation FNV, the largest Dutch career site Monsterboard, the University of Amsterdam and the Amsterdams Instituut voor Arbeidsstudies (AIAS). The website attracts over a hundred thousand visitors and has more than a million page views monthly. Particularly, its Salary Check appears to be a great crowd magnet, as it provides reliable information about average wages earned in 130 occupations, controlled for characteristics such as education and years of service. In order to generate up-to-date information on wages earned, the web visitors are asked to complete a questionnaire. Approximately one out of every hundred visitors does so. Initially, the website and the questionnaire addressed women only, but since May 2001 it has aimed at attracting both genders. The data set used in this study covers the data collected from mid-May 2001 until mid-April 2002.

To ascertain how representative the data set was, the distribution across gender and age was compared with data from the Statline database 2000, primarily based on the Labour Force Survey (LFS-2000) and collected by Statistics Netherlands. Because the questionnaire initially aimed at women only, women were overrepresented in the data set. In addition, both men and women aged 25-34 were overrepresented, whereas men and women aged 45-54 were underrepresented. Because of the magnitude of the deviations, we weighted the sample for gender and age. The weighted sample does not show any significant deviations between the WIQ-2001/02 and the LFS-2000 according to industries (see Table 4).

The initial data set used has 16,269 person observations. We excluded the few self-employed and freelancers, and the observations with missing values for industry, firm size, region, presence of children, and career break. To avoid our wage estimations being affected by outliers, we excluded the observations with 1 percent of the lowest and 1 percent of the highest wage distribution. From the sample with information on education level, we kept all observations except for those indicating the education level as "something else". As a result, we worked with 12,757 observations.

Table 4 Comparison of Wage Indicator Questionnaire (WIQ) 2001/02 (N=16,269) and the LFS data 2000: employees by gender and age, and by gender and industry

\begin{tabular}{|c|c|c|c|c|c|c|}
\hline \multirow[b]{2}{*}{ Age } & \multicolumn{2}{|c|}{ Employees in WIQ-2001/02 } & \multicolumn{2}{|c|}{ Employees in LFS-2000 } & \multicolumn{2}{|c|}{ Differences in \%-points } \\
\hline & Women & Men & Women & Men & Women & Men \\
\hline $15-24$ & $17.8 \%$ & $13.7 \%$ & $14.9 \%$ & $11.8 \%$ & $2.9 \%$ & $1.8 \%$ \\
\hline $25-34$ & $47.4 \%$ & $45.1 \%$ & $32.6 \%$ & $28.4 \%$ & $14.8 \%$ & $16.7 \%$ \\
\hline
\end{tabular}




\begin{tabular}{|c|c|c|c|c|c|c|}
\hline $35-44$ & $23.2 \%$ & $26.3 \%$ & $27.6 \%$ & $28.2 \%$ & $-4.4 \%$ & $-2.0 \%$ \\
\hline $45-54$ & $10.4 \%$ & $12.5 \%$ & $20.0 \%$ & $23.4 \%$ & $-9.6 \%$ & $-10.9 \%$ \\
\hline $55-64$ & $1.3 \%$ & $2.4 \%$ & $4.9 \%$ & $8.1 \%$ & $-3.6 \%$ & $-5.7 \%$ \\
\hline Total in \% & $100 \%$ & $100 \%$ & $100 \%$ & $100 \%$ & $0 \%$ & $0 \%$ \\
\hline total $\mathrm{N}$ & 8895 & 7374 & 2.487 .000 & 3.629 .000 & - & - \\
\hline Industry & weighted & weighted & & & & \\
\hline Manufacturing & $7.6 \%$ & $23.3 \%$ & $4.6 \%$ & $21.3 \%$ & $-3.1 \%$ & $-2.1 \%$ \\
\hline Commercial services & $19.5 \%$ & $25.8 \%$ & $16.0 \%$ & $24.7 \%$ & $-3.5 \%$ & $-1.1 \%$ \\
\hline Non-commercial services & $13.4 \%$ & $10.3 \%$ & $19.9 \%$ & $13.4 \%$ & $6.6 \%$ & $3.2 \%$ \\
\hline total in \% & $40.6 \%$ & $59.4 \%$ & $40.6 \%$ & $59.4 \%$ & $0 \%$ & $0 \%$ \\
\hline total $\mathrm{N}$ & 6530 & 9567 & 2.414 .000 & 3.539 .000 & - & - \\
\hline
\end{tabular}

Source: Wage Indicator Questionnaire 2001/02 and CBS-Statline 2000.

\subsection{The Variables Used in the Equations}

The data set is useful for our analysis, because it has detailed information on wages, hours, firm characteristics, industry, employment history, household characteristics, and the usual human capital characteristics. The dependent variable in the earnings equation of the labour force in wage employment is the natural log of the hourly wage in euros from the current job, excluding overtime pay, shift premium, bonuses, commission, or allowances, but including the 8 percent holiday premium when such a premium is reported. The hourly rates are based on the contractual hours worked per week, the payment, and the period covered by the payment, which is usually one month, but could be four weeks, one week, one hour or even one year. If the reported contractual weekly hours are zero or close to zero, the actual weekly working hours were used for calculating the hourly wages.

The explanatory variables have been derived from Section 2. Education is measured in years from age 12. Experience is measured as total years worked in paid employment, thus excluding the years due to a career break longer than one year. To control for the non-linear effect of experience, we also use experience squared. In addition, we use tenure, indicating the years worked with the current employer. Furthermore, we control for the gender effect holding education and experience constant. Two variables characterize the respondent's job: a part-time job, and a permanent contract. Two household-related variables indicate whether the respondent has one or more children living at home, and whether there has been a career break due to children. Moreover, we include gender and ethnicity, as is common in inter-industry wage differentials. Two dummy variables indicate ethnicity: one indicating that the person was born 
outside the Netherlands but in Europe, the other indicating that the person was born outside Europe. In addition, in studies of industry wage effects, geographical differentials persist. We therefore take into account four provinces in the Netherlands, together representing approximately half of the labour force in the country, leaving the remaining provinces as the reference group. Finally, firm size is included in the analyses, including two categories of small firms: firms up to 10 employees and firms with 10-100 employees, leaving the category of large firms with 100 employees and over as the reference group.

\subsection{Description of the Data}

Table 5 shows the mean values of the variables used in the analyses. Average wage rates are highest in the 1-digit non-commercial services, followed by the 3-digit IT-services. Wages are lowest in the 1-digit commercial services and in 3-digit entertainment. This seems in line with the results of Throsby (1994). The wage differentials between the 3-digit printing and publishing and its 1-digit manufacturing are small, while the differences between the 3-digit IT-services and its 1-digit commercial services are large, in favour of the former; and the differences between the 3digit entertainment sub-industry and its 1-digit non-commercial services are large as well, in favour of the latter.

Table 5 also shows that education levels vary substantially across all three pairs of industries, but that, at first sight, no clear pattern exists between levels of education and wage rates. The preliminary inspection of the data shows both relatively low wages in the entertainment industry and relatively low education levels. Education is the highest in the 3-digit IT-services. Tenure increases with actual experience and varies substantially across the industries. As could be expected, it is lowest in the 3-digit IT-services, and highest in the 1-digit manufacturing and noncommercial services. The lower tenure and actual experience in the cultural industries in general, compared with the main industries, characterize these sub-industries as younger than the main industries.

The share of permanent jobs is the largest in IT services and the lowest in entertainment. The share of part-time jobs appears to be related to the share of women, with the non-commercial services ranking highest and manufacturing ranking lowest. As regards the presence of children, the large difference between the entertainment industry and the non-commercial services is remarkable. In the former, the percentage of employees with children is lowest at 27 percent, while in the latter it is highest at 47 percent. The share of women in the industry varies substantially across the mean. The non-commercial services rank highest with 71 percent female workers and manufacturing ranks lowest with 27 percent females. The percentage of non-Dutch, both European and non-European, is highest in the IT services, whereas in the other industries it 
does not vary much across the mean, except for a lower percentage of persons with a nonEuropean background in the entertainment industry.

The mean values for the four provinces reveal a large variation across the industries. The share of the respondents in the entertainment industry working in the Province of North-Holland is large, which is in line with statistics presented elsewhere (Raspe and Segeren, 2004; Kloosterman, 2004), whereas the workers in the non-commercial services are predominantly found in the Province of South-Holland, and the workers in manufacturing are overrepresented in the Province of North-Brabant. Finally, firm size varies substantially across the mean, with high shares of workers in the entertainment industry predominantly employed in smaller firms, and rarely in firms with more than 100 employees. Both IT-services and non-commercial services show relatively low shares of employees in small firms.

Table 5 Mean values of the logarithm of the gross hourly wage and all explanatory variables by industry

\begin{tabular}{|c|c|c|c|c|c|c|c|}
\hline & All & $\begin{array}{l}\text { Publishing } \\
\text { and printing }\end{array}$ & $\begin{array}{l}\text { Manu- } \\
\text { facturing } \\
\text { excl.P\&P }\end{array}$ & IT-services & $\begin{array}{l}\text { Commercial } \\
\text { services, } \\
\text { excl. IT }\end{array}$ & Entertainment & $\begin{array}{l}\text { Non- } \\
\text { commercial } \\
\text { services, } \\
\text { excl. entert. }\end{array}$ \\
\hline Log gross hourly wage in euros & 2.56 & 2.55 & 2.54 & 2.61 & 2.51 & 2.52 & 2.66 \\
\hline Education (years) & 12.24 & 11.73 & 11.69 & 13.19 & 12.24 & 12.22 & 12.81 \\
\hline Experience (years) & 11.80 & 11.93 & 13.43 & 9.46 & 10.31 & 9.46 & 13.61 \\
\hline Experience squared (years) & 219.86 & 218.98 & 271.48 & 143.97 & 173.09 & 153.60 & 276.62 \\
\hline Tenure (years) & 5.18 & 5.32 & 6.81 & 3.23 & 4.02 & 3.41 & 6.22 \\
\hline Education*gender & 5.56 & 5.27 & 7.35 & 6.16 & 5.54 & 3.74 & 3.82 \\
\hline Experience *gender & 5.96 & 6.70 & 9.29 & 4.66 & 4.95 & 3.56 & 4.79 \\
\hline Experience squared*gender & 123.15 & 130.07 & 201.87 & 75.29 & 91.97 & 60.43 & 113.85 \\
\hline Gender ( $0=$ female, $1=$ male) & 0.45 & 0.46 & 0.63 & 0.46 & 0.44 & 0.32 & 0.29 \\
\hline Permanent contract $[0,1]$ & 0.93 & 0.94 & 0.95 & 0.97 & 0.92 & 0.84 & 0.92 \\
\hline Part-time job $[0,1]$ & 0.24 & 0.17 & 0.13 & 0.17 & 0.23 & 0.30 & 0.40 \\
\hline Re-entrant $[0,1]$ & 0.24 & 0.20 & 0.21 & 0.20 & 0.23 & 0.24 & 0.29 \\
\hline Child $[0,1]$ & 0.38 & 0.36 & 0.43 & 0.35 & 0.32 & 0.27 & 0.47 \\
\hline Ethnic (non-Dutch Europe) [0,1] & 0.03 & 0.04 & 0.03 & 0.06 & 0.03 & 0.04 & 0.03 \\
\hline
\end{tabular}




\begin{tabular}{lccccccc}
\hline Ethnic (non-Dutch non-Europe) [0,1] & 0.06 & 0.05 & 0.05 & 0.09 & 0.06 & 0.03 & 0.05 \\
Province North-Holland [0,1] & 0.21 & 0.33 & 0.15 & 0.27 & 0.23 & 0.42 & 0.18 \\
Province South-Holland [0,1] & 0.22 & 0.14 & 0.20 & 0.21 & 0.22 & 0.19 & 0.25 \\
Province Zeeland [0,1] & 0.02 & 0.01 & 0.03 & 0.01 & 0.02 & 0.04 & 0.02 \\
Province North-Brabant [0,1] & 0.14 & 0.13 & 0.19 & 0.13 & 0.13 & 0.12 & 0.12 \\
Employed in firm $\leq 10$ employees [0,1] & 0.14 & 0.17 & 0.12 & 0.08 & 0.18 & 0.23 & 0.09 \\
Employed in firm > 10 and $\leq 100$ employ.. [0,1] & 0.42 & 0.49 & 0.46 & 0.46 & 0.44 & 0.51 & 0.32 \\
N & 12757 & 404 & 2996 & 236 & 6130 & 158 & 2833 \\
\hline
\end{tabular}

Source: Wage Indicator Questionnaire 2001/02, weighted data.

Note: All dichotomous variables are coded $0=$ no, and $1=$ yes.

\section{Results: Earnings Functions by Industries}

The estimation results are shown in Table $6{ }^{4}$. All earning functions include human capital, the interaction of gender and human capital, job characteristics, children, being a re-entrant in the labour market, firm size, and region. As expected, many explanatory variables are significant. Education and experience have a positive effect on the hourly wage of employees from all groups, as expected, although the extent and the significance level of the coefficients vary along the samples. Education is rewarded the most in commercial services, and experience in entertainment. The lowest reward for education and for an additional year of experience is found for workers in publishing and printing. Tenure does not affect hourly wage significantly, except for the workers in the commercial services industry where it has a significantly positive effect. Furthermore, we find that men are paid less than women for similar education in non-commercial services, and slightly less in the manufacturing industry and commercial services. We do not find a gender difference in rewards for each additional year of experience in any of the industries. The highest reward from a permanent contract is found in the entertainment industry. However, in the manufacturing industry and in non-commercial services having a permanent contract also affects wages significantly positively. Having a part-time job only has a significant effect on the wages of workers in commercial services, and there the effect is negative. Having a non-European background pays off compared with the majority of the Dutch employees in the entertainment 
industry, and having a non-Dutch European background pays off in the manufacturing industry compared with employees with another ethnic background. We found that an ethnic background has no significant effect on wages in the other industries.

Furthermore, we estimate the effect that being a re-entrant has on wages. A re-entrant is defined as returning to work after a break of at least one year. To have had a career break makes employees in all industries significantly worse off. The penalty due to a career break is the worst in the sub-industry of publishing and printing compared with the workers in manufacturing, but it is also significant in commercial and non-commercial services. Accounting for gender, part-time job and being a re-entrant, the effect of children is significantly positive in all industries, except for the IT-services industries and entertainment where no significant effect is found. Furthermore, workers in commercial services excluding IT, and in the IT-sub-industry in the province of North-Holland, are significantly better paid than their colleagues in other regions in the Netherlands. Workers in the non-commercial services in South-Holland are paid better than their colleagues in other regions in the Netherlands. Workers in commercial services are paid less in North-Brabant. Workers in small firms, both firms with 10 employees or less and firms with more than 10 but less than 100 or exactly 100 employees, are paid less than workers in establishments with more than 100 employees in all industries, except in the entertainment industry and in IT-services in where we do not find a significant effect of firm size on wages. These negative effects on payment are very strong; they are strongest for workers in firms with up to 10 employees and for workers in publishing and printing. These findings seem to support the hypothesis of the shirking model, concerning the higher monitoring costs of large firms. 


\begin{tabular}{|c|c|c|c|c|c|c|}
\hline & $\mathrm{P} \& \mathrm{P}$ & $\begin{array}{l}\text { M excl. } \\
\text { P\&P }\end{array}$ & IT & $\begin{array}{l}\text { CS Excl. } \\
\text { IT }\end{array}$ & $\begin{array}{c}\text { Entertain- } \\
\text { ment }\end{array}$ & $\begin{array}{l}\text { Non-CS } \\
\text { excl. } \\
\text { entertain. }\end{array}$ \\
\hline Education (years) & $\begin{array}{c}0.058 \\
(0.008)^{* *}\end{array}$ & $\begin{array}{c}0.083 \\
(0.004)^{* *}\end{array}$ & $\begin{array}{c}0.073 \\
(0.012)^{* *}\end{array}$ & $\begin{array}{c}0.091 \\
(0.003)^{* *}\end{array}$ & $\begin{array}{c}0.071 \\
(0.013)^{* *}\end{array}$ & $\begin{array}{c}0.081 \\
(0.003)^{* *}\end{array}$ \\
\hline Education*gender & $\begin{array}{l}-0.010 \\
(0.011)\end{array}$ & $\begin{array}{c}-0.011 \\
(0.005)^{*}\end{array}$ & $\begin{array}{l}-0.016 \\
(0.018)\end{array}$ & $\begin{array}{c}-0.008 \\
(0.004)^{*}\end{array}$ & $\begin{array}{l}-0.016 \\
(0.021)\end{array}$ & $\begin{array}{c}-0.013 \\
(0.005)^{* *}\end{array}$ \\
\hline Experience (years) & $\begin{array}{c}0.024 \\
(0.006)^{* *}\end{array}$ & $\begin{array}{c}0.029 \\
(0.003)^{* *}\end{array}$ & $\begin{array}{c}0.034 \\
(0.012)^{* *}\end{array}$ & $\begin{array}{c}0.035 \\
(0.002)^{* *}\end{array}$ & $\begin{array}{c}0.040 \\
(0.011)^{* *}\end{array}$ & $\begin{array}{c}0.027 \\
(0.002)^{* *}\end{array}$ \\
\hline Experience* gender & $\begin{array}{c}0.013 \\
(0.008)\end{array}$ & $\begin{array}{c}0.005 \\
(0.004)\end{array}$ & $\begin{array}{c}0.018 \\
(0.016)\end{array}$ & $\begin{array}{c}0.003 \\
(0.003)\end{array}$ & $\begin{array}{l}-0.025 \\
(0.019)\end{array}$ & $\begin{array}{c}0.003 \\
(0.004)\end{array}$ \\
\hline Experience squared*gender & $\begin{array}{c}0.000 \\
(0.000)\end{array}$ & $\begin{array}{c}0.000 \\
(0.000)\end{array}$ & $\begin{array}{l}-0.001 \\
(0.001)\end{array}$ & $\begin{array}{c}0.000 \\
(0.000)\end{array}$ & $\begin{array}{c}0.001 \\
(0.001)\end{array}$ & $\begin{array}{c}0.000 \\
(0.000)\end{array}$ \\
\hline Experience squared (years) & $\begin{array}{c}0.000 \\
(0.000)^{*}\end{array}$ & $\begin{array}{c}-0.001 \\
(0.000)^{* *}\end{array}$ & $\begin{array}{l}-0.001 \\
(0.000)\end{array}$ & $\begin{array}{c}-0.001 \\
(0.000)^{* *}\end{array}$ & $\begin{array}{c}-0.001 \\
(0.000)^{*}\end{array}$ & $\begin{array}{c}0.000 \\
(0.000)^{* *}\end{array}$ \\
\hline Tenure & $\begin{array}{c}0.002 \\
(0.002)\end{array}$ & $\begin{array}{c}0.002 \\
(0.001)\end{array}$ & $\begin{array}{c}0.007 \\
(0.006)\end{array}$ & $\begin{array}{c}0.004 \\
(0.001)^{* *}\end{array}$ & $\begin{array}{l}-0.001 \\
(0.005)\end{array}$ & $\begin{array}{c}0.001 \\
(0.001)\end{array}$ \\
\hline Tenure (years) & $\begin{array}{c}0.088 \\
(0.048)\end{array}$ & $\begin{array}{c}0.088 \\
(0.023)^{* *}\end{array}$ & $\begin{array}{c}0.033 \\
(0.107)\end{array}$ & $\begin{array}{c}0.009 \\
(0.014)\end{array}$ & $\begin{array}{c}0.172 \\
(0.062)^{* *}\end{array}$ & $\begin{array}{c}0.069 \\
(0.018)^{* *}\end{array}$ \\
\hline Permanent contract $[0,1]$ & $\begin{array}{c}0.088 \\
(0.048)\end{array}$ & $\begin{array}{c}0.088 \\
(0.023)^{* *}\end{array}$ & $\begin{array}{c}0.033 \\
(0.107)\end{array}$ & $\begin{array}{c}0.009 \\
(0.014)\end{array}$ & $\begin{array}{c}0.172 \\
(0.062)^{* *}\end{array}$ & $\begin{array}{c}0.069 \\
(0.018)^{* *}\end{array}$ \\
\hline Part-time $[0,1]$ & $\begin{array}{l}-0.028 \\
(0.034)\end{array}$ & $\begin{array}{l}-0.015 \\
(0.017)\end{array}$ & $\begin{array}{l}-0.022 \\
(0.053)\end{array}$ & $\begin{array}{c}-0.035 \\
(0.010)^{* *}\end{array}$ & $\begin{array}{c}0.026 \\
(0.053)\end{array}$ & $\begin{array}{c}0.005 \\
(0.011)\end{array}$ \\
\hline Ethnicity non-Dutch Europe & $\begin{array}{c}0.014 \\
(0.047)\end{array}$ & $\begin{array}{c}0.081 \\
(0.022)^{* *}\end{array}$ & $\begin{array}{c}0.051 \\
(0.065)\end{array}$ & $\begin{array}{c}0.007 \\
(0.016)\end{array}$ & $\begin{array}{c}-0.017 \\
(0.106)\end{array}$ & $\begin{array}{c}0.037 \\
(0.021)\end{array}$ \\
\hline Ethnicity non-Dutch non-Europe & $\begin{array}{c}-0.120 \\
(0.071)\end{array}$ & $\begin{array}{c}-0.029 \\
(0.032)\end{array}$ & $\begin{array}{c}-0.019 \\
(0.088)\end{array}$ & $\begin{array}{c}0.009 \\
(0.021)\end{array}$ & $\begin{array}{c}0.292 \\
(0.144)^{*}\end{array}$ & $\begin{array}{l}-0.044 \\
(0.030)\end{array}$ \\
\hline Gender ( 0 =female, $1=$ male) & $\begin{array}{c}0.048 \\
(0.149)\end{array}$ & $\begin{array}{c}0.120 \\
(0.066)\end{array}$ & $\begin{array}{c}0.126 \\
(0.255)\end{array}$ & $\begin{array}{c}0.137 \\
(0.049)^{* *}\end{array}$ & $\begin{array}{c}0.460 \\
(0.292)\end{array}$ & $\begin{array}{c}0.222 \\
(0.068)^{* *}\end{array}$ \\
\hline Child $[0,1]$ & $\begin{array}{c}0.059 \\
(0.029)^{*}\end{array}$ & $\begin{array}{c}0.033 \\
(0.012)^{* *}\end{array}$ & $\begin{array}{c}0.002 \\
(0.050)\end{array}$ & $\begin{array}{c}0.051 \\
(0.010)^{* *}\end{array}$ & $\begin{array}{c}0.103 \\
(0.061)\end{array}$ & $\begin{array}{c}0.037 \\
(0.012)^{* *}\end{array}$ \\
\hline Re-entrant $[0,1]$ & $\begin{array}{c}-0.066 \\
(0.030)^{*}\end{array}$ & $\begin{array}{c}-0.041 \\
(0.013)^{* *}\end{array}$ & $\begin{array}{c}-0.096 \\
(0.049)\end{array}$ & $\begin{array}{c}-0.035 \\
(0.010)^{* *}\end{array}$ & $\begin{array}{c}0.037 \\
(0.056)\end{array}$ & $\begin{array}{c}-0.047 \\
(0.012)^{* *}\end{array}$ \\
\hline Province North-Holland & $\begin{array}{c}0.052 \\
(0.027)\end{array}$ & $\begin{array}{c}0.023 \\
(0.015)\end{array}$ & $\begin{array}{c}0.101 \\
(0.047)^{*}\end{array}$ & $\begin{array}{c}0.070 \\
(0.010)^{* *}\end{array}$ & $\begin{array}{c}0.083 \\
(0.058)\end{array}$ & $\begin{array}{c}0.013 \\
(0.013)\end{array}$ \\
\hline Province South-Holland & $\begin{array}{c}0.053 \\
(0.035)\end{array}$ & $\begin{array}{c}0.010 \\
(0.013)\end{array}$ & $\begin{array}{c}0.039 \\
(0.052)\end{array}$ & $\begin{array}{c}0.009 \\
(0.010)\end{array}$ & $\begin{array}{l}-0.031 \\
(0.067)\end{array}$ & $\begin{array}{c}0.034 \\
(0.012)^{* *}\end{array}$ \\
\hline Province Zeeland & $\begin{array}{c}0.024 \\
(0.120)\end{array}$ & $\begin{array}{c}-0.031 \\
(0.030)\end{array}$ & $\begin{array}{c}0.085 \\
(0.172)\end{array}$ & $\begin{array}{l}-0.018 \\
(0.030)\end{array}$ & $\begin{array}{l}-0.046 \\
(0.119)\end{array}$ & $\begin{array}{c}-0.041 \\
(0.033)\end{array}$ \\
\hline Province North-Brabant & $\begin{array}{c}0.038 \\
(0.037)\end{array}$ & $\begin{array}{c}0.000 \\
(0.014)\end{array}$ & $\begin{array}{c}0.024 \\
(0.064)\end{array}$ & $\begin{array}{c}-0.025 \\
(0.012)^{*}\end{array}$ & $\begin{array}{c}-0.065 \\
(0.077)\end{array}$ & $\begin{array}{c}0.002 \\
(0.016)\end{array}$ \\
\hline Employed in firm $\leq 10$ empl. $[0,1]$ & $\begin{array}{c}-0.185 \\
(0.034)^{* *}\end{array}$ & $\begin{array}{c}-0.147 \\
(0.017)^{* *}\end{array}$ & $\begin{array}{c}-0.131 \\
(0.077)\end{array}$ & $\begin{array}{c}-0.127 \\
(0.011)^{* *}\end{array}$ & $\begin{array}{c}0.038 \\
(0.066)\end{array}$ & $\begin{array}{c}-0.135 \\
(0.017)^{* *}\end{array}$ \\
\hline Employed in firm $\leq 100 \&>10$ empl. $[0,1]$ & $\begin{array}{c}-0.104 \\
(0.026)^{* *}\end{array}$ & $\begin{array}{c}-0.076 \\
(0.011)^{* *}\end{array}$ & $\begin{array}{l}-0.081 \\
(0.041)\end{array}$ & $\begin{array}{c}-0.073 \\
(0.009)^{* *}\end{array}$ & $\begin{array}{l}-0.072 \\
(0.054)\end{array}$ & $\begin{array}{c}-0.051 \\
(0.011)^{* *}\end{array}$ \\
\hline Constant & $\begin{array}{c}1.613 \\
(0.114)^{* *}\end{array}$ & $\begin{array}{c}1.234 \\
(0.058)^{* *}\end{array}$ & $\begin{array}{c}1.381 \\
(0.193)^{* *}\end{array}$ & $\begin{array}{c}1.152 \\
(0.037)^{* *}\end{array}$ & $\begin{array}{c}1.163 \\
(0.193)^{* *}\end{array}$ & $\begin{array}{c}1.297 \\
(0.039)^{* *}\end{array}$ \\
\hline $\mathrm{N}$ & 404 & 2996 & 236 & 6130 & 158 & 2833 \\
\hline Rsq & 0.46 & 0.42 & 0.42 & 0.43 & 0.50 & 0.49 \\
\hline
\end{tabular}

Source: Wage Indicator Survey 2001/02.

Key: P\&P: publishing and printing; M: manufacturing industry; CS: commercial services: IT: IT services; Entertain: entertainment industry; excl. excluding. Means of variables are in Table 5. Description of variables in Section 4. 


\section{Results: Analysis of Wage Differentials}

\section{a. Decomposition of Wage Differentials}

The decomposition results are obtained by Equation (3), using estimated coefficients and mean values of the explanatory variables presented in Table 6 . Table 7 summarizes the results of the decomposition of the wage differentials between employees in the sub-industry and its main industry, within the selected industries. We use the STATA 8.2 command on decomposing wage differentials. The raw differential consists of the endowments (E) component of the decomposition, and the coefficients (C) component, and the interaction between $\mathrm{C}$ and $\mathrm{E}$. The results are very different for the three comparisons we make. Table 7 shows that the raw differential between the cultural sub-industry and the main industry is only positive in IT services versus commercial services, as expected from the turnover model and the selection model, and to a small extent in publishing and printing (P\&P) versus manufacturing, also as expected. However, it is negative for entertainment versus non-commercial services. Only workers in the IT industry have more endowments compared with their respective main industry. The negative raw differential for entertainment compared with the main industry relates to workers having less endowments in entertainment. However, being paid less for endowments is only a minor reason for the lower payments of workers in cultural industries versus non-commercial services. This leads us to reject all expectations, as described in Table 3, as explanations of workers' wages in entertainment. However, our results are in line with the findings in Throsby (1994).

Table 7 Summary of decomposition results

\begin{tabular}{llll}
\hline & $\begin{array}{l}\text { Publishing \& printing } \\
\text { versus } \\
\text { Manufacturing, excl. } \\
\text { P\&P }\end{array}$ & $\begin{array}{l}\text { IT services versus } \\
\text { Commercial services, } \\
\text { excl. IT }\end{array}$ & $\begin{array}{l}\text { Entertainment versus } \\
\text { Non-commercial services, } \\
\text { excl. entertainment }\end{array}$ \\
\hline Raw differential (E+C+CE) & 0.008 & 0.096 & -14.09 \\
- due to characteristics (E) & -0.033 & 0.091 & -14.10 \\
- due to price or evaluation related & & & -0.006 \\
effects (C) & 0.043 & 0.025 & 0.008 \\
\hline
\end{tabular}

Source: Wage Indicator Survey 2001/02. 
Table 8 gives a more detailed presentation of the decomposition results by showing each variable. The column "E" shows the wage differential that can be attributed to the difference in observable characteristics. A positive figure means that the employee in the sub-industry has higher qualifications than an employee in the respective 1-digit level industry, and a negative figure means the opposite. Price or evaluation related effects are shown in column " $\mathrm{C}$ " and indicate that, given their observable characteristics, the payment per hour is different in the sub-industry compared with its 1-digit level industry. Positive price or evaluation related effects indicate that the workers in the sub-industry earn more per hour than workers in the respective 1-digit level industry with similar characteristics, and a negative figure means the opposite. We also show the interaction between $\mathrm{C}$ and $\mathrm{E}$ in column ("CE”). The interaction between $\mathrm{C}$ and $\mathrm{E}$ is mostly minor in effects, except for experience in the entertainment sub-industry which leads to a negative effect.

Regarding human capital, workers in IT services have higher education levels than workers in commercial services, whereas workers in entertainment have lower education levels than workers in non-commercial services. In all sub-industries the level of education obtained is much less rewarded than in the respective 1-digit industries, in line with the results on the performing, visual and literary arts by Throsby (1994) and the review by Blaug (2001). However, the negative effects in P\&P and in the IT services, compared with their respective main industries, are strikingly high. Moreover, workers in the sub-industries have less accumulated years of actual experience compared with the main industries. Especially in the entertainment industry, the accumulation of years of experience is far below that of workers in non-commercial services. However, an additional year of experience for workers in the entertainment industry is rewarded highly, compared with how it is rewarded for workers in non-commercial services. In contrast, an additional year of actual experience does not itself lead to improved wages for workers in the IT services, compared to other commercial services; but longer experience pays more in IT services, compared with other commercial services. However, tenure with the employer pays less in IT services compared to commercial services, suggesting that IT services hire people with high education, recent experience, and who are mobile in the labour market. Employees in P\&P are much less rewarded than workers in the manufacturing industry for each additional year of experience. In all the cultural industries, the negative price effect for human capital is the main cause for workers earning lower wages compared with other workers in their respective main industry. 
Table 8 Detailed Decomposition Results: (groups of) variables

\begin{tabular}{|c|c|c|c|c|c|c|c|c|c|}
\hline & \multicolumn{3}{|c|}{$\begin{array}{l}\text { Publish \& printing versus } \\
\text { manufacturing }\end{array}$} & \multicolumn{3}{|c|}{$\begin{array}{l}\text { IT-services versus Commercial } \\
\text { services excl IT }\end{array}$} & \multicolumn{3}{|c|}{$\begin{array}{l}\text { Entertainment versus non- } \\
\text { commercial services excl. } \\
\text { entertainment }\end{array}$} \\
\hline & $\mathrm{E}$ & $\mathrm{C}$ & $\mathrm{CE}$ & $\mathrm{E}$ & $\mathrm{C}$ & $\mathrm{CE}$ & $\mathrm{E}$ & $\mathrm{C}$ & CE \\
\hline Education (years) & 0.004 & -0.292 & -0.001 & 0.090 & -0.220 & -0.020 & -0.050 & -0.130 & 0.010 \\
\hline Experience (years) & -0.043 & -0.062 & 0.007 & -0.030 & -0.010 & 0.000 & -0.110 & 0.180 & -0.060 \\
\hline Experience squared (years) & 0.027 & 0.020 & -0.004 & 0.020 & 0.030 & 0.000 & 0.050 & -0.070 & 0.030 \\
\hline Tenure & -0.002 & 0.002 & 0.000 & 0.000 & -0.050 & 0.010 & 0.000 & -0.010 & 0.010 \\
\hline Subtotal human capital & -0.014 & -0.332 & 0.002 & 0.080 & -0.250 & -0.010 & -0.110 & -0.030 & -0.010 \\
\hline Education*gender & 0.022 & 0.009 & -0.002 & 0.000 & 0.010 & 0.000 & 0.000 & -0.010 & 0.000 \\
\hline Experience*gender & -0.016 & 0.074 & -0.023 & -0.010 & -0.050 & -0.010 & 0.000 & -0.130 & 0.030 \\
\hline Experience squared*gender & 0.004 & -0.045 & 0.016 & 0.000 & 0.080 & 0.000 & 0.000 & 0.070 & -0.030 \\
\hline Gender [0=female, $1=$ male $]$ & -0.021 & -0.045 & 0.012 & 0.000 & -0.010 & 0.000 & 0.010 & 0.070 & 0.010 \\
\hline Subtotal gender & -0.011 & -0.007 & 0.003 & -0.010 & 0.030 & -0.010 & 0.010 & 0.000 & 0.010 \\
\hline Permanent contract $[0,1]$ & -0.001 & 0.001 & 0.000 & 0.000 & 0.020 & 0.000 & -0.010 & 0.100 & -0.010 \\
\hline Part-time job $[0,1]$ & -0.001 & -0.002 & -0.001 & 0.000 & 0.000 & 0.000 & 0.000 & 0.010 & 0.000 \\
\hline Subtotal job characteristics & -0.002 & -0.001 & -0.001 & 0.000 & 0.020 & 0.000 & -0.010 & 0.110 & -0.010 \\
\hline Ethnicity Non-Dutch Europe & 0.001 & -0.003 & -0.001 & 0.000 & 0.000 & 0.000 & 0.000 & 0.000 & 0.000 \\
\hline Ethnicity Non-Dutch non-Europe & 0.000 & -0.002 & 0.000 & 0.000 & 0.000 & 0.000 & 0.000 & 0.010 & 0.000 \\
\hline Subtotal ethnicity & 0.001 & -0.005 & -0.001 & 0.000 & 0.000 & 0.000 & 0.000 & 0.010 & 0.000 \\
\hline Child $[0,1]$ & -0.002 & 0.011 & -0.002 & 0.000 & -0.020 & 0.000 & -0.010 & 0.030 & -0.010 \\
\hline Re-entrant $[0,1]$ & 0.000 & -0.005 & 0.000 & 0.000 & -0.010 & 0.000 & 0.000 & 0.030 & -0.010 \\
\hline Subtotal children & -0.002 & 0.006 & -0.002 & 0.000 & -0.030 & 0.000 & -0.010 & 0.060 & -0.020 \\
\hline Province North-Holland & 0.004 & 0.004 & 0.005 & 0.000 & 0.010 & 0.000 & 0.000 & 0.010 & 0.020 \\
\hline Province South-Holland & 0.000 & 0.009 & -0.002 & 0.000 & 0.010 & 0.000 & 0.000 & -0.020 & 0.000 \\
\hline Province Zeeland & 0.001 & 0.002 & -0.001 & 0.000 & 0.000 & 0.000 & 0.000 & 0.000 & 0.000 \\
\hline Province North-Brabant & 0.000 & 0.007 & -0.002 & 0.000 & 0.010 & 0.000 & 0.000 & -0.010 & 0.000 \\
\hline Subtotal region & 0.005 & 0.022 & 0.000 & 0.000 & 0.030 & 0.000 & 0.000 & -0.020 & 0.020 \\
\hline Firm $\leq 10$ employees $[0,1]$ & -0.008 & 0.004 & -0.002 & 0.010 & 0.000 & 0.000 & -0.020 & 0.020 & 0.020 \\
\hline Firm $>10$ and $\leq 100$ empl. empl.[0,1] & -0.002 & -0.013 & -0.001 & 0.000 & 0.000 & 0.000 & -0.010 & -0.010 & 0.000 \\
\hline Subtotal firm size & -0.010 & -0.009 & -0.003 & 0.010 & 0.000 & 0.000 & -0.030 & 0.010 & 0.020 \\
\hline constant & 0.000 & 0.379 & 0.000 & 0.000 & 0.230 & 0.000 & 0.000 & -0.130 & 0.000 \\
\hline Total & -0.033 & 0.043 & -0.002 & 0.091 & 0.025 & -0.020 & -0.140 & -0.006 & 0.008 \\
\hline
\end{tabular}

Source: Wage Indicator Questionnaire 2001/02.

Key: C: endowment effect; E: 'Price' or evaluation-related effect; CE: interaction effect of endowment and 'price' or evaluation-related effect. Software used for calculations STATA 8.2 command decompose. 
As for gender, there are less women employed in P\&P than in manufacturing, and more in entertainment than in non-commercial services. Women are paid less in P\&P and in IT services compared with the main industries, but female workers earn more in entertainment than in noncommercial services. Women with the same education as men earn slightly more or less in the sub-industries compared with the main industries, but for the same level of experience the differences between men and women in the sub-industries compared with the main industries are large. However, for the same level of experience, female workers earn much lower wages in the entertainment industry and in IT services. In contrast, women with the same years of experience earn higher wages in P\&P compared with the main industries. However, the higher the amount of experience the woman has, the smaller the gender difference of wage per year of experience will be in entertainment and IT services, but the bigger the gender difference in wage per year of experience will be in $\mathrm{P} \& \mathrm{P}$ versus the manufacturing industry. Regarding job characteristics, such as permanent contract and working part time, we only find a large difference in entertainment compared with non-commercial services, which means that a permanent contract pays better in entertainment.

There are not more re-entrants in the cultural industries than in their respective main industries, and the effect of having a career break affects the wages negatively in the P\&P and IT services industries compared with their respective main industries. However, re-entrants in entertainment, compared with re-entrants in non-commercial services, earn more.

A non-European background has some positive price or evaluation related effects in entertainment compared with non-commercial services. All other effects of an ethnic background are very small.

The wage differences between sub-industries compared with their respective main industries are small, as regards province and firm size. But all these effects accord with the expectations described in Section 2.3.

\section{Conclusions}

The examination of wage levels in the cultural industries, rather than in specific cultural occupations, has led to a close examination of the definitions of workers in the cultural industries. In our study cultural industries comprised Publishing and Printing (P\&P), IT services and Internet firms, and entertainment. Identification was based on internationally-defined coding by Eurostat and Statistics Netherlands.

Explanations of why employers pay higher wages in the cultural industries are thought to be related to the innovative character of these industries. In particular the technology-driven innovation of products and services may lead to employers paying higher wages to workers, because of the above average abilities that are required to perform well in such creative jobs in a 
dynamic market. However, in our analysis of wages in the three sub-industries of the cultural industries and the main one-digit industry to which each belongs, the question "Are workers in the cultural industries paid better or worse?” leads to different answers.

Our preliminary inspection of the data of the three pairs of selected industries does indeed show that workers in sub-industries are characterized by less tenure, less actual experience in years, and slightly higher education (except for entertainment) compared with the main industries to which they belong. All these facts characterize these sub-industries as younger than the main industries. Workers in the entertainment industry are less covered by permanent contracts than in any other industry, and they are much more often employed part-time (as in the main non-commercial services), in small establishments, and about 40 percent of these workers are employed in the Province of North-Holland. Workers in P\&P are also mostly employed in North-Holland. These characteristics make these workers very different from other workers. However, the pay differentials between the sub-industry and the main industry is negative only in the entertainment industries. For the most part, this negative effect is explained by less endowment of human capital, that is, fewer years of experience, but there is also a negative 'price' or evaluation-related effect in this industry pair. However, overall, the negative price effect of education in all subindustries of cultural industries compared with their respective main industrial sector requires a closer examination.

\section{Acknowledgements}

An earlier version of this paper was presented at the Twelfth International Biennial Conference organized by the Association of Cultural Economics International, Rotterdam, 13-15 June 2002, and at seminars at the University of Rotterdam in 2006 and the University of Amsterdam in 2005. This research was partly funded by the TNO-STB research program the "Cultural Industries". I thank Kea Tijdens for an earlier discussion of this paper. She was also responsible for the project that collects the Wage Indicator Survey data. Helpful comments by three anonymous referees are gratefully acknowledged.

\section{Notes}

1. The German philosophers Theodor Adorno and Max Horkheimer used the term "culture industry” for the first time (Adorno and Horkheimer 1944). In this article we discuss the definition of cultural industries and identify cultural industries empirically in section 2.2.

2. This definition spread by UNESCO (see www.unesco.org) is based on the notion that cultural industries add value to contents and generate values for individuals and societies. They are 
knowledge and labour-intensive, create employment and wealth, nurture creativity - the "raw material" they are made from -, and foster innovation in production and commercialization processes. At the same time, cultural industries are central in promoting and maintaining cultural diversity and in ensuring democratic access to culture. This twofold nature -both cultural and economic - builds up a distinctive profile for cultural industries.

3. Kloosterman (2002) works with a basic and a broader definition of cultural industries applying SBI-coding. The basic definition includes similar codes as presented in Table 1 except the 925 and the IT sector. The broader definition by Kloosterman (2002) is similar to Scott (2000), which includes all trade and production of products such as shoes and clothing factories, publishers, furniture industries, but does also not include SBI-codes 720, and 721.

4. In appendix Tables A.1 and A.2 we estimated wage equations for all workers with interaction dummies for all regressors with the cultural industries that we distinguish. Appendix Table A.1 shows the results when we include interaction with the constant in column 1 and without interaction with the constant (column 2). Including the interaction between P\&P and the constant makes the effect of education negative in P\&P compared to other workers and makes the constant for P\&P significantly and highly positive. In entertainment the opposite is found. Including the dummy for the constant in entertainment makes the effect of education insignificant in entertainment. All other effects are similar between the two columns. Compared to all workers' wages, workers in a) publishing and printing earn higher wages if they are male but not if controlled for education level, and if they work in Zuid-Holland, in b) earn higher wages if they working in Noord-Holland, and c) in entertainment if they work for small firms, have children, and if they are female with similar levels of experience. Appendix Table A.2. shows similar regressions but then for the distinguished main industries with interaction dummies for sub-industries. Again we include the constant in the first column per industry, and leave the constant for sub-industry out in the second column. Compared to Appendix Table 1 there are some changes in results. Holding main industry features constant we find no effect of different wages for workers in IT, in addition to effects in Table A.1 we find negative effects on wages for workers in P\&P compared with other manufacturing industries as regards being born outside Europe and being a re-entrant. For workers in entertainment compared to non-commercial services we find compared to Table A.1. an additional positive effect from working in Noord-Holland.

\section{References}

Abbing, H. (2002), Why Are Artists Poor? Amsterdam University Press, Amsterdam.

Adorno, Th. and M. Horkheimer (1944), "The Culture Industry: Enlightenment as Mass Deception”, in: Dialectic of Enlightenment. Dialektik der Aufklärung, Philosophische 
Geschrifte, Fischer, Amsterdam.

Altonji, J.G. and R. M. Blank (1999), Race and Gender in the Labor Market, in: O. Ashenfelter and D. Card (eds). Handbook of Labor Economics, Volume 3, pp. 3143-3213.

Becker, G.S. (1962), Investment in Human Capital: a theoretical analysis, Journal of Political Economy, 70: 9-49.

Bartel, A. and N. Sicherman (1999), "Technological Change and Wages: an Inter-industry Analysis”, Journal of Political Economy 107, (2), 285-325.

Blaug, M. (2001), “Where Are We Now on Cultural Economics?”, Journal of Economic Surveys 15 (2), 123-143.

Blackburn, McKinley L. (1995), “Decomposing Wage Variation”, Journal of Human Resources 30, 853-861.

Blinder, A. (1973), "Wage Discrimination: Reduced Form and Structural Estimates”, Journal of Human Resources 8, 436-455.

CBS (1993), Standaard BedrijfsIndeling (1993), Index per bedrijfs(sub)klasse, Centraal Bureau voor de Statistiek, Voorburg.

Daymont, T.N. and P.J. Andrisani (1984), Job Preferences, College Major, and The Gender Gap In Earnings, Journal of Human Resources 19, 408-428.

Ducatel, K., J-C. Burgelman, M. Bogdanowicz (2000), Employment outlook and occupational change in the media content industries (2000-2005). Scenarios and background note. Brussels/Luxembourg, European Commission.

Fields, Judith and Edward N. Wolff (1995), "Interindustry Wage Differentials and the Gender Wage Gap”, Industrial and Labor Relations Review 49, 105-120.

Filer, R.K. (1986), “The 'starving artist'- myth or reality? Earnings of artists in the United States”. Journal of Political Economy 94, 56-76, reprinted in Towse (1997a,II), 227-46.

Kloosterman, R.C. (2002), De stad, de cultuur en het geld; een eerste cijfermatige exercitie rond cultural industries in Nederland, Stedenbouw en Ruimtelijke Ordening, 02.

Kloosterman, R.C. (2004), "Recent Employment Trends in the Cultural Industries in Amsterdam, Rotterdam, The Hague and Utrecht”, Tijdschrift voor Economische en Sociale Geografie 95(2), 243-252.

Krueger, Alan B. and Lawrence H. Summers (1988), "Efficiency Wages and the Inter-Industry Wage Structure”, Econometrica 56, 259-293.

Mincer, J. (1974), Schooling, Experience and Earnings. New York: Columbia University Press.

Oaxaca, R.L. (1973), “Male-female Wage Differentials in Urban Labour Markets”. International Economic Review 14, 693-709.

Osburn, Jane (2000), “Inter-industry Wage Differentials: Patterns and Possible Sources”, Monthly Labor Review 123(2), 34-44.

Pagniet, Geraldine (2002), “The Cultural Industries and Development”, The Courier ACP-EU, 194, September-October.

Raspe O. and A. Segeren (2004), “Cultural Industries” binnen de Nederlandse agglomeraties, paper presented at stadsdag Nethur/RSA Nederlands 'De cultuur van de lokale economie, de economie van de lokale cultuur'. Ruimtelijk Plan Bureau, Den Haag.

Rengers, M. and O. Velthuis (2002), "Determinants of Prices for Contemporary Art in Dutch Galleries, 1992-1998”. Journal of Cultural Economics 26, 1-28.

Rosen, S. (1981), “The Economics of Superstars”, American Economic Review 71(5), 845-858.

Rutten, P. (1999), De toekomst van de verbeeldingsmachine. De culturele industrie in de 
eenentwintigste eeuw.Rotterdam: Inaugural lecture Erasmus University Rotterdam, October 22.

Scott, A.J. (2000), “The Cultural Economy of Cities”, in: M. Featherstone (ed.), Theory, Culture and Society. Sage Publications, London, Thousand Oaks, New Delhi.

Thorsby, D. (1994), "The Production and Consumption of the Arts: A View of Cultural Economics”, Journal of Economic Literature 32, 1-29.

Tijdens, K.G. (2004), The database, measurement issues and the methodology of the Dutch Wage Indicator Internet Survey, AIAS working paper 2004/25, Amsterdam.

Tijdens, K.G., A. Dragstra, D. Dragstra, M. van Klaveren, P. Osse, C. Wetzels and A. Zorlu (2002), Loonwijzers 2001/2002. Werk, lonen en beroepen van mannen en vrouwen in Nederland. Amsterdam, AIAS Research Report RR02/10, www.uvaaias.net/files/aias/RR10.pdf, Amsterdam.

Wetzels, C. and K.G. Tijdens (2001), Towards a Digital Dutch Miracle in Households and Firms?, TNO-Report 0017, Institute for Applied Scientific Research, Delft. 


\section{Appendix Table A 1: OLS wage regressions Total Workers. Coefficients and (standard deviations)}

education

experience

Experience squared

tenure

Education*gender

Experience*gender

Experience squared*gender

Permanent contract

Part-time job

Ethnicity non-Dutch Europe

Ethnicity non-Dutch non-Europe

$1=$ male $0=$ female

Having children

Re-entrant

province=North-holland

province=South-Holland

province $=$ Zeeland

province=North-brabant

Firm size •10 employees

Firm size $>10 \& \bullet 100$ empl.

$1=$ publishing and printing

Publish\&Print*education

Publish\&Print*experience

Publish\&Print*exp.squared

Publish\&Print*tenure

Publish\&Print*educ*gender

Publish\&Print*exp*gender

Publish\&Print*exp squared*gender
(1)

0.088

$(0.002) * *$

0.031

$(0.001) * *$

$-0.001$

$(0.000) * *$

0.003

$(0.001) * *$

$-0.008$

$(0.002) * *$

0.004

$(0.002)$ *

0.000

(0.000)

0.039

$(0.010)$ *

$-0.011$

(0.007)

0.029

$(0.011)$ *

$-0.010$

(0.015)

0.120

$(0.032)$ **

0.042

$(0.007)$ *

$-0.039$

$(0.007)$ **

0.047

$(0.007)$ **

0.015

$(0.007)$ *

$-0.027$

(0.018)

$-0.014$

(0.008)

$-0.139$

$(0.008) * *$

$-0.075$

$(0.006)$ **

0.416

(0.145)**

$-0.030$

$(0.010) * *$

$-0.007$

(0.008)

0.000

(0.000)

$-0.001$

(0.003)

$-0.002$

(0.014)

0.010

(0.011)

0.000

(0.000)
(2)

0.087

$(0.002) * *$

0.031

$(0.001) * *$

$-0.001$

$(0.000) * *$

0.003

$(0.001) * *$

$-0.007$

$(0.002) * *$

0.004

$(0.002)$ *

0.000

(0.000)

0.038

$(0.010)$ *

$-0.011$

(0.007)

0.029

(0.011)*

$-0.010$

(0.015)

0.109

$(0.032) * *$

0.042

$(0.007)$ *

$-0.040$

$(0.007)$ * *

0.047

$(0.007)$ **

0.015

$(0.007)$ *

$-0.027$

(0.018)

$-0.015$

(0.008)

$-0.140$

$(0.008)$ **

$-0.076$

$(0.006)$ *

$-0.006$

$(0.005)$

0.000

(0.007)

0.000

$(0.000)$

$-0.001$

(0.003)

$-0.023$

(0.012)

0.002

(0.010)

0.000

(0.000) 


\begin{tabular}{|c|c|c|}
\hline \multirow[t]{2}{*}{ Publish\&Print*permanent } & 0.049 & 0.109 \\
\hline & $(0.061)$ & $(0.057)$ \\
\hline \multirow[t]{2}{*}{ Publish\&Print*part-time } & -0.017 & -0.014 \\
\hline & $(0.043)$ & $(0.043)$ \\
\hline \multirow[t]{2}{*}{ Publish\&Print*non_Dutch Europe } & -0.015 & -0.017 \\
\hline & $(0.060)$ & $(0.060)$ \\
\hline \multirow[t]{2}{*}{ Publish\&Print*non-Dutch non Europe } & -0.110 & -0.097 \\
\hline & $(0.090)$ & $(0.090)$ \\
\hline \multirow[t]{2}{*}{ Publish\&Print*gender } & -0.073 & 0.228 \\
\hline & $(0.190)$ & $(0.158)$ \\
\hline \multirow[t]{2}{*}{ Publish\&Print*re-entrant } & -0.027 & -0.011 \\
\hline & $(0.038)$ & $(0.037)$ \\
\hline \multirow[t]{2}{*}{ Publish\&Print*chld } & 0.017 & 0.015 \\
\hline & $(0.037)$ & $(0.037)$ \\
\hline \multirow[t]{2}{*}{ Publish\&Print*Province N-Holland } & 0.005 & 0.021 \\
\hline & $(0.034)$ & $(0.034)$ \\
\hline \multirow[t]{2}{*}{ Publish\&Print*Province S-Holland } & 0.038 & 0.052 \\
\hline & $(0.044)$ & $(0.044)$ \\
\hline \multirow[t]{2}{*}{ Publish\&Print*Province Zeeland } & 0.051 & 0.090 \\
\hline & $(0.152)$ & $(0.152)$ \\
\hline \multirow[t]{2}{*}{ Publish\&Print*Province N-Brabant } & 0.052 & 0.066 \\
\hline & $(0.048)$ & $(0.047)$ \\
\hline \multirow[t]{2}{*}{ Publish\&Print*Firm size less or 10 employ. } & -0.046 & -0.012 \\
\hline & $(0.044)$ & $(0.042)$ \\
\hline \multirow[t]{2}{*}{ Publish\&Print*Firm size 10-100 employ } & -0.029 & -0.005 \\
\hline & $(0.034)$ & $(0.033)$ \\
\hline \multirow[t]{2}{*}{$1=i t$ services } & 0.184 & \\
\hline & $(0.193)$ & \\
\hline \multirow[t]{2}{*}{ IT*education } & -0.015 & -0.006 \\
\hline & $(0.012)$ & $(0.008)$ \\
\hline \multirow[t]{2}{*}{$I T *$ experience } & 0.003 & 0.006 \\
\hline & $(0.012)$ & $(0.012)$ \\
\hline \multirow[t]{2}{*}{ IT*experience squared } & 0.000 & 0.000 \\
\hline & $(0.000)$ & $(0.000)$ \\
\hline \multirow[t]{2}{*}{ IT*tenure } & 0.004 & 0.004 \\
\hline & $(0.006)$ & $(0.006)$ \\
\hline IT*education*gender & -0.008 & -0.017 \\
\hline & $(0.018)$ & $(0.015)$ \\
\hline $\mathrm{IT}$ *experience*gender & 0.015 & 0.011 \\
\hline & $(0.016)$ & $(0.015)$ \\
\hline$I T * \exp$. squared*gender & -0.001 & 0.000 \\
\hline & $(0.001)$ & $(0.001)$ \\
\hline IT*permanent & -0.006 & 0.038 \\
\hline & $(0.106)$ & $(0.096)$ \\
\hline IT*part-time & -0.011 & -0.011 \\
\hline & $(0.053)$ & $(0.053)$ \\
\hline IT*non Dutch Europe & 0.022 & 0.027 \\
\hline & $(0.065)$ & $(0.065)$ \\
\hline IT*non Dutch non Europe & -0.009 & -0.013 \\
\hline & $(0.088)$ & $(0.088)$ \\
\hline$I T *$ gender & 0.006 & 0.149 \\
\hline & $(0.255)$ & $(0.207)$ \\
\hline IT*re-entrant & -0.057 & -0.055 \\
\hline & $(0.049)$ & $(0.049)$ \\
\hline$I T * \operatorname{child}$ & -0.040 & -0.042 \\
\hline & $(0.050)$ & $(0.050)$ \\
\hline IT*Province N-Holland & 0.054 & 0.056 \\
\hline & $(0.047)$ & $(0.047)$ \\
\hline IT*Province S-Holland & 0.023 & 0.024 \\
\hline
\end{tabular}




\begin{tabular}{|c|c|c|}
\hline & $(0.052)$ & $(0.052)$ \\
\hline \multirow[t]{2}{*}{ IT*Province Zeeland } & 0.111 & 0.101 \\
\hline & $(0.172)$ & $(0.171)$ \\
\hline \multirow[t]{2}{*}{ IT*Province N-Brabant } & 0.038 & 0.044 \\
\hline & $(0.064)$ & $(0.063)$ \\
\hline \multirow[t]{2}{*}{ IT*Firm size less or 10 employ. } & 0.008 & 0.014 \\
\hline & $(0.077)$ & $(0.077)$ \\
\hline \multirow[t]{2}{*}{ IT*Firm size 10-100 employ. } & -0.006 & 0.001 \\
\hline & $(0.041)$ & $(0.041)$ \\
\hline \multirow[t]{2}{*}{$1=$ entertainment } & -0.034 & \\
\hline & $(0.208)$ & \\
\hline \multirow[t]{2}{*}{ entertain*education } & -0.016 & -0.018 \\
\hline & $(0.014)$ & $(0.007) * *$ \\
\hline \multirow[t]{2}{*}{ entertain*experience } & 0.009 & 0.008 \\
\hline & $(0.012)$ & $(0.011)$ \\
\hline \multirow[t]{2}{*}{ entertain*exp.squared } & 0.000 & 0.000 \\
\hline & $(0.000)$ & $(0.000)$ \\
\hline \multirow{2}{*}{ entertain*tenure } & -0.003 & -0.003 \\
\hline & $(0.006)$ & $(0.006)$ \\
\hline \multirow[t]{2}{*}{ entertain*education*gender } & -0.008 & -0.006 \\
\hline & $(0.023)$ & $(0.020)$ \\
\hline \multirow[t]{2}{*}{ entertain*experience* gender } & -0.028 & -0.028 \\
\hline & $(0.021)$ & $(0.021)$ \\
\hline \multirow[t]{2}{*}{ entertain*exp. Sq*gender } & 0.001 & 0.001 \\
\hline & $(0.001)$ & $(0.001)$ \\
\hline \multirow[t]{2}{*}{ entertain*permanent } & 0.133 & 0.132 \\
\hline & $(0.067) *$ & $(0.066) *$ \\
\hline \multirow[t]{2}{*}{ entertain*part-time } & 0.037 & 0.036 \\
\hline & $(0.058)$ & $(0.057)$ \\
\hline \multirow[t]{2}{*}{ entertain*non-Dutch Europe } & -0.046 & -0.043 \\
\hline & $(0.114)$ & $(0.114)$ \\
\hline \multirow[t]{2}{*}{ entertain*non-Dutch non-Europe } & 0.302 & 0.296 \\
\hline & $(0.155)$ & $(0.152)$ \\
\hline \multirow[t]{2}{*}{ entertain*gender } & 0.340 & 0.315 \\
\hline & $(0.314)$ & $(0.271)$ \\
\hline \multirow[t]{2}{*}{ entertain*re-entrant } & 0.076 & 0.074 \\
\hline & $(0.060)$ & $(0.059)$ \\
\hline \multirow[t]{2}{*}{ entertain*chid } & 0.061 & 0.062 \\
\hline & $(0.066)$ & $(0.065)$ \\
\hline \multirow[t]{2}{*}{ entertain*Province $\mathrm{N}$-Holland } & 0.036 & 0.036 \\
\hline & $(0.062)$ & $(0.062)$ \\
\hline entertain*Province S-Holland & -0.046 & -0.049 \\
\hline & $(0.072)$ & $(0.071)$ \\
\hline entertain*Province Zeeland & -0.020 & -0.021 \\
\hline & $(0.128)$ & $(0.128)$ \\
\hline entertain*Province $\mathrm{N}$-Brabant & -0.050 & -0.052 \\
\hline & $(0.083)$ & $(0.083)$ \\
\hline entertain*Firm size less or 10 employ. & 0.177 & 0.174 \\
\hline & $(0.071) *$ & $(0.069) *$ \\
\hline entertain*Firm size 10-100 employ. & 0.003 & 0.000 \\
\hline & $(0.058)$ & $(0.055)$ \\
\hline Constant & 1.197 & 1.211 \\
\hline & $(0.024) * *$ & $(0.024) * *$ \\
\hline Observations & 12757 & 12757 \\
\hline R-squared & 0.45 & 0.45 \\
\hline $\begin{array}{l}\text { Source: Wage Indicator Survey } 2001 / 200 \\
\text { significant at the } 1 \% \text { level. }\end{array}$ & ant at 10 & cant at $5 \%$ \\
\hline
\end{tabular}




\section{Appendix Table A2. OLS wage regressions by main industry. Coefficients and (standard deviations)}

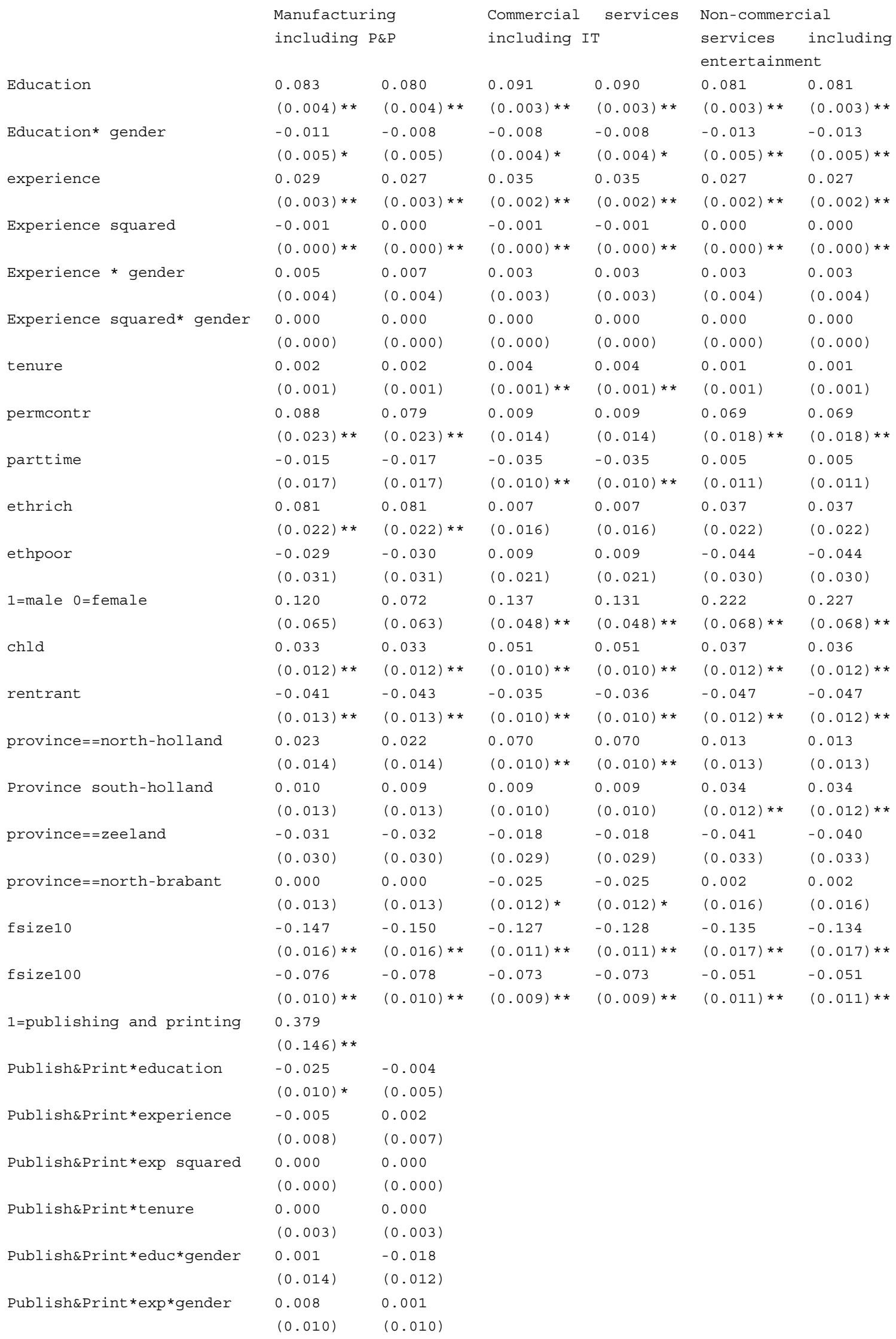




\begin{tabular}{|c|c|c|c|c|}
\hline Publish\&Print*expsq*gender & $\begin{array}{l}0.000 \\
(0.000)\end{array}$ & $\begin{array}{l}0.000 \\
(0.000)\end{array}$ & & \\
\hline Publish\&Print*permanent & $\begin{array}{l}0.001 \\
(0.061)\end{array}$ & $\begin{array}{l}0.056 \\
(0.057)\end{array}$ & & \\
\hline Publish\&Print*part time & $\begin{array}{l}-0.013 \\
(0.043)\end{array}$ & $\begin{array}{l}-0.008 \\
(0.043)\end{array}$ & & \\
\hline $\begin{array}{l}\text { Publish\&Print*non-Dutch } \\
\text { Europe }\end{array}$ & -0.067 & -0.069 & & \\
\hline & $(0.059)$ & $(0.059)$ & & \\
\hline $\begin{array}{l}\text { Publish\&Print*non-Dutch } \\
\text { non-Europe }\end{array}$ & -0.091 & -0.081 & & \\
\hline & $(0.089)$ & $(0.089)$ & & \\
\hline Publish\&Print*gender & $\begin{array}{l}-0.072 \\
(0.187)\end{array}$ & $\begin{array}{l}0.207 \\
(0.153)\end{array}$ & & \\
\hline Publish\&Print*re-entrant & $\begin{array}{l}-0.025 \\
(0.037)\end{array}$ & $\begin{array}{l}-0.010 \\
(0.037)\end{array}$ & & \\
\hline Publish\&Print*child & $\begin{array}{l}0.026 \\
(0.037)\end{array}$ & $\begin{array}{l}0.024 \\
(0.037)\end{array}$ & & \\
\hline $\begin{array}{l}\text { Publish\&Print*Province N- } \\
\text { Holland }\end{array}$ & 0.029 & 0.042 & & \\
\hline & $(0.035)$ & $(0.034)$ & & \\
\hline $\begin{array}{l}\text { Publish\&Print*Province S- } \\
\text { Holland }\end{array}$ & $(0.043)$ & $(0.043)$ & & \\
\hline $\begin{array}{l}\text { Publish\&Print*Province } \\
\text { Zeeland }\end{array}$ & 0.055 & 0.087 & & \\
\hline & $(0.145)$ & $(0.145)$ & & \\
\hline $\begin{array}{l}\text { Publish\&Print*Province N- } \\
\text { Brabant }\end{array}$ & 0.038 & 0.049 & & \\
\hline & $(0.046)$ & $(0.046)$ & & \\
\hline Publish\&Print*Firm size & -0.038 & -0.009 & & \\
\hline & $(0.044)$ & $(0.042)$ & & \\
\hline Publish\&Print*Firm size & -0.028 & -0.008 & & \\
\hline & $(0.033)$ & $(0.032)$ & & \\
\hline $1=I t$ services & & & $\begin{array}{l}0.229 \\
(0.206)\end{array}$ & \\
\hline Publish\&Print*education & & & $\begin{array}{l}-0.049 \\
(0.054)\end{array}$ & $\begin{array}{l}-0.051 \\
(0.054)\end{array}$ \\
\hline IT*experience & & & $\begin{array}{l}-0.018 \\
(0.013)\end{array}$ & $\begin{array}{l}-0.007 \\
(0.008)\end{array}$ \\
\hline$I T * \exp$ squared & & & $\begin{array}{l}-0.008 \\
(0.019)\end{array}$ & $\begin{array}{l}-0.019 \\
(0.016)\end{array}$ \\
\hline IT*tenure & & & $\begin{array}{l}-0.028 \\
(0.095)\end{array}$ & $\begin{array}{l}-0.034 \\
(0.095)\end{array}$ \\
\hline IT*educ*gender & & & $\begin{array}{l}0.043 \\
(0.070)\end{array}$ & $\begin{array}{l}0.050 \\
(0.070)\end{array}$ \\
\hline$I T *$ exp*gender & & & $\begin{array}{l}0.000 \\
(0.000)\end{array}$ & $\begin{array}{l}0.000 \\
(0.000)\end{array}$ \\
\hline IT*expsq*gender & & & $\begin{array}{l}-0.001 \\
(0.001)\end{array}$ & $\begin{array}{l}0.000 \\
(0.001)\end{array}$ \\
\hline IT*permanent & & & $\begin{array}{l}-0.001 \\
(0.013)\end{array}$ & $\begin{array}{l}0.003 \\
(0.012)\end{array}$ \\
\hline IT*part-time & & & $\begin{array}{l}0.016 \\
(0.017)\end{array}$ & $\begin{array}{l}0.011 \\
(0.016)\end{array}$ \\
\hline IT*non-Dutch Europe & & & $\begin{array}{l}-0.004 \\
(0.082)\end{array}$ & 0.004 \\
\hline IT*non-Dutch non-Europe & & & -0.008 & 0.000 \\
\hline
\end{tabular}


Entertain*Province Zeeland

Entertain*Province N-

Brabant

Entertain*Firm size less

or 10 employ.

Entertain*Firm size 10-100

employ.

Constant

Observations

R-squared

$\begin{array}{ll}1.234 & 1.292 \\ (0.057) * * & (0.052) * * \\ 3400 & 3400\end{array}$

3400

0.43
0.021

$(0.053)$

0.084

(0.055)

0.238

(0.290)

$-0.002$

$(0.005)$

1.152

1. 160

$(0.036) * *$

6366

0.43

0.017

(0.052)

0.077

6366

0.43

1. 297

(0.054)

0.136

Source: Wage Indicator Survey 2001/02.

Standard errors in parentheses.

* significant at the 5\% level; ** significant at the $1 \%$ level 